\title{
In vitro evaluation of antifungal activity of Aloe vera, Moringa oleifera and Newbouldia laevis on the Strain of Lasiodiplodia theobromae in Region of Kisangani / DR CONGO
}

\author{
Kwembe JTK ${ }^{1}$, Mbula $\mathrm{JP}^{1}$, Onautshu $\mathrm{O}^{2 *}$, Mpiana $\mathrm{PT}^{3}$, Haesaert $\mathrm{G}^{4}$ \\ ${ }^{1}$ Department of Chemistry, Faculty of Sciences, University of Kisangani, B.P. 2012 Kisangani, DR Congo \\ ${ }^{2}$ Department of Biotechnological Sciences, Faculty of Sciences, University of Kisangani, B.P. 2012 Kisangani, DR Congo \\ ${ }^{3}$ Department of Chemistry, Faculty of Sciences, University of Kinshasa, B.P. 190 Kinshasa XI, DR Congo \\ ${ }^{4}$ Department of Plants and Cultures, Faculty of Biosciences Engineering, University of Ghent, Ghent 9000, Belgium
}

DOI: $10.36348 /$ sb.2020.v06i05.002 | Received: 24.04.2020 | Accepted: 01.05.2020 | Published: 21.05 .2020

*Corresponding author: Didy Onautshu Odimba

\section{Abstract}

This work is part of the fight against in vitro the growth of Lasiodiplodia theobromae with some medicinal plants including Aloe vera, Moringa oleifera and Newbouldia laevis. This fungus causes brown cocoa rot in the Kisangani region. The antifungal activity of the crude, aqueous, ethanolic and ethereal extracts of fresh and dried leaves of the plants studied were evaluated in vitro by six repetitions on Potato dextrose agar medium. After two days of incubation, the raw extract of the fresh leaves of $M$. oleifera inhibited the growth of $L$. theobromae by up to $74.1 \%$ followed by that of $A$. vera (29.6\%) and $N$. laevis (14.7\%). The aqueous, ethanolic and ethereal extracts of the fresh leaves of M. oleifera revealed respective inhibition percentages of 43.0; 53.3 and 71.1. As for the extracts of the dry leaves, A. vera was active with its ethereal extract $(58.1 \%)$ and ethanolic extract $(56.7 \%)$. Notwithstanding, $M$. oleifera remains the very active plant with an excellent inhibition rate of $74.1 \%$ having considerably slowed down the maximum growth time of $L$. theobromae by reducing it from two days for the control to six days for the raw extract. Although the plant extracts studied have a fungistatic effect, their purification by extraction of phytochemical groups in our next studies, could reveal their respective fungicidal properties.

Keywords: Activity, antifungal, Aloe vera, Lasiodiplodia theobromae, Moringa oleifera, Newbouldia laevis, Kisangani.

Copyright @ 2020: This is an open-access article distributed under the terms of the Creative Commons Attribution license which permits unrestricted use, distribution, and reproduction in any medium for non-commercial use (NonCommercial, or CC-BY-NC) provided the original author and source are credited.

\section{INTRODUCTION}

Agriculture, one of the main sources of income in the world and particularly in sub-Saharan Africa [1], faces several constraints including that caused by parasites thus reducing the yield of the harvest [2]. Theobroma cacao is planted in several botanical homes around the world, particularly in the tropical zone for its beans used in the manufacture of chocolate and the extraction of vegetable fats known as butters [3]. However, around the 1980, cocoa orchards displayed an unusual dieback disease, observed in all cocoa producing areas of Cameroon, affecting $100 \%$ of cocoa trees in certain plantations [4].

\section{Lasiodiplodia theobromae (syn.} Botryodiplodia theobromae), a common endophyte and an opportunistic pathogen on more than 500 tree species in tropical and subtropical regions [5], was first reported on cocoa in Cameroon in $1895[6,7]$. This fungus is the basis of the decline of the cocoa tree and is often isolated from twigs, bark, vascular tissue and the affected cocoa pod [4]. L. theobromae is becoming an increasingly dangerous threat to cocoa cultivation not only in India [8], Cameroon and Western Samoa, the Philippines [9], but also in the region of Kisangani at Democratic Republic of Congo.

Traditionally, to fight against certain phytopathogenic germs, farmers most often use chemical synthesis products as pesticide. Unfortunately the use of these is not without danger for the health of farmers and consumers [10]. In addition, the new regulations discourage the use of synthetic fungicides for fear of the appearance of new resistant pathogenic germs $[11,12]$ and thus these rules limit the potential risks for human health as well as environmental pollution $[13,14]$. 
Certain approaches are in the making based on biological control by the isolation and screening of microbial antagonists as biological agents acting against L. theobromae [9]. But in the region of Kisangani, no initiative has been reported so far to limit or stop the invasion of cocoa fields by $L$. theobromae by using plants as a means of control, so this work serves as a light in this field.

Several studies have shown that plants have an antimicrobial and / or antifungal effect on certain phytopathogenic or zoopathogenic germs. Natural bioactive products can be extracted from plant species with significant antifungal activity, including Aloe vera [15], Moringa oleifera [16] and Newbouldia laevis [17].

Thus, this investigation consisted to evaluate in vitro the antifungal activity of the extracts of these plants on the strain of $L$. theobromae responsible for brown cocoa rot. This work is part of the objective of meeting the current trend which consists of the formulation of biofungicides from plants which naturally are biodegradable, effective, and accessible to all budgets and in addition are reputed as renewable resources.

\section{MATERIALS AND METHODS Study environment}

This work was carried out in the Kisangani region, capital of the Tshopo province in the Democratic Republic of Congo (Figure 1). The city of Kisangani is located at $0^{\circ} 31$ 'north latitude, from the Equator $(57 \mathrm{~km}), 25^{\circ} 11^{\prime}$ east longitude from the Greenwich meridian, and 428 meters above sea level $[18,19]$.

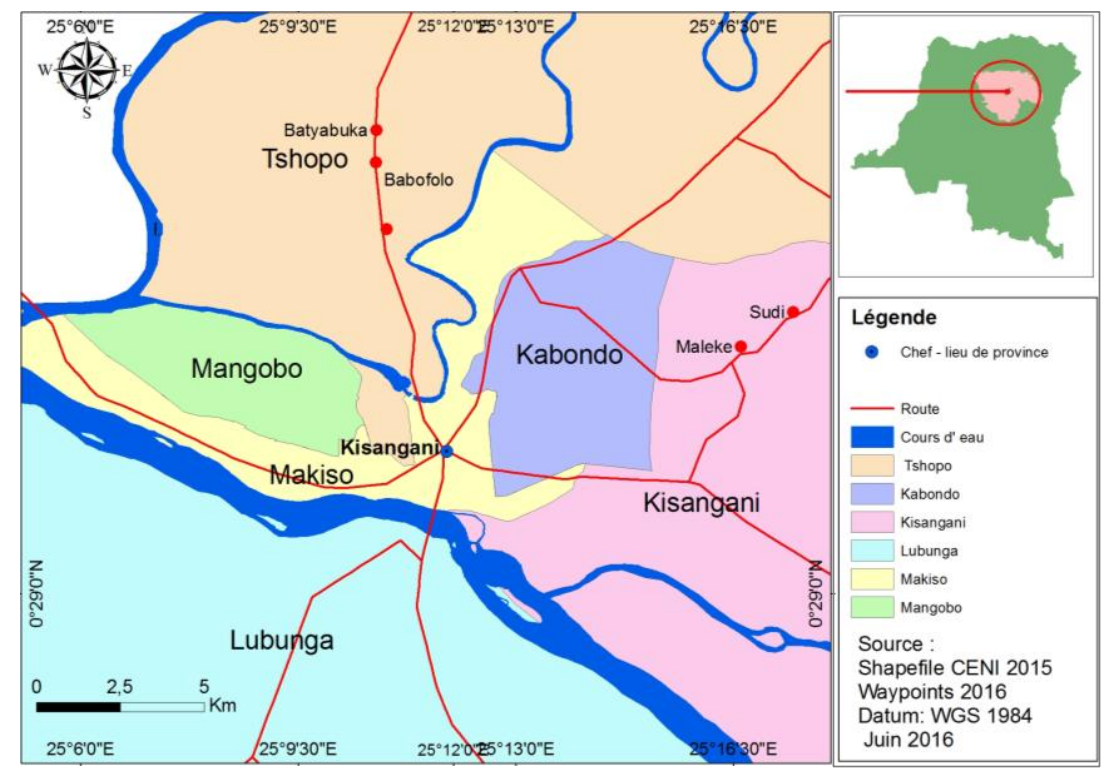

Fig-1: Map of the Kisangani region

\section{Plants and treatment}

The leaves of $A$. vera, $M$. oleifera and $N$. laevis were harvested in the region of Kisangani to serve as plant material after being identified by the Herbarium service of the Faculty of Sciences of the University of Kisangani. Three different batches were made up for each plant in order to obtain three different types of extracts: raw extract from fresh pressed leaves; extract of fresh macerated leaves and extract of dry macerated leaves.

For this, $10 \mathrm{~g}$ of plant materials (fresh leaves or dry leaf powder) were macerated for 48 hours in 50 $\mathrm{ml}$ of solvent consisting of distilled water for the aqueous extract, $95 \%$ ethanol for the ethanolic extract and diethyl ether for the ethereal extract. The macerated filtrates were concentrated in an oven at $40^{\circ} \mathrm{C}$, and at a rate of $2 \mathrm{ml}$ of the concentrate from $10 \mathrm{ml}$ of the macerated filtrate.

\section{Obtaining the fungal strain}

The L. theobromae strain was isolated from cocoa pod naturally affected by brown rot. These pods were harvested directly from the tree in the cocoa plantations of Bengamisa (CABEN) and Yangambi respectively $37 \mathrm{~km}$ on the Kisangani-Buta road axis and $90 \mathrm{~km}$ on the Kisangani-Yangambi road axis. After washing the cocoa pod, a rotten piece was removed, washed with $5 \%$ bleach and rinsed in sterile distilled water to finally be seeded on potato dextrose agar (PDA) at $25^{\circ} \mathrm{C}$ in the dark for 5 days. Transplanting was carried out on PDA at $25 \pm 2{ }^{\circ} \mathrm{C}$ under permanent white light. To prevent bacteria from growing, $100 \mu \mathrm{L}$ of Ampicillin (50mg / ml) and $100 \mu \mathrm{L}$ of Chloramphenicol $(50 \mathrm{mg} / \mathrm{ml})$ were added beforehand to each $100 \mathrm{ml}$ of PDA at $45^{\circ} \mathrm{C}$ before solidification. 


\section{Assessment of antifungal activity}

The antifungal activity was evaluated on the basis of percentage inhibition (PI) of mycelial growth or reduction of mycelial growth (RCM) of plant extracts on the strain of $L$. theobromae, with six repetitions. $12 \mathrm{ml}$ of PDA was poured into each $90 \mathrm{~mm}$ diameter Petri dish. A line was drawn in advance on the median of the Petri dish, one half to apply the extracts and the mycelial explant of $5 \mathrm{~mm}$ in diameter, was placed on the other half at $2.5 \mathrm{~mm}$ from the median line [20]. Mycelial growth was measured on either side of the midline (Fungal Ray, R.F) each after 24 hours until the Petri dish was filled. The control was carried out in the same conditions but without extract.
The PI calculation was performed by this formula:

$$
P I=\frac{(\text { F. R control }- \text { R. F. Extract) }}{\text { R. F. control }} \times 100
$$

The R 3.4.0 software was used to compare the means of the PI by performing the one-factor variance analysis test. The standard deviation was calculated by the standard deviations shown in the error bar on the histograms.

\section{RESULTS \\ Inhibition percentage}

Extraction solvents

The sensitivity of the fungal strain to extraction solvents was assessed in the sense of evaluating their antifungal activities as illustrated in figure 2 below.

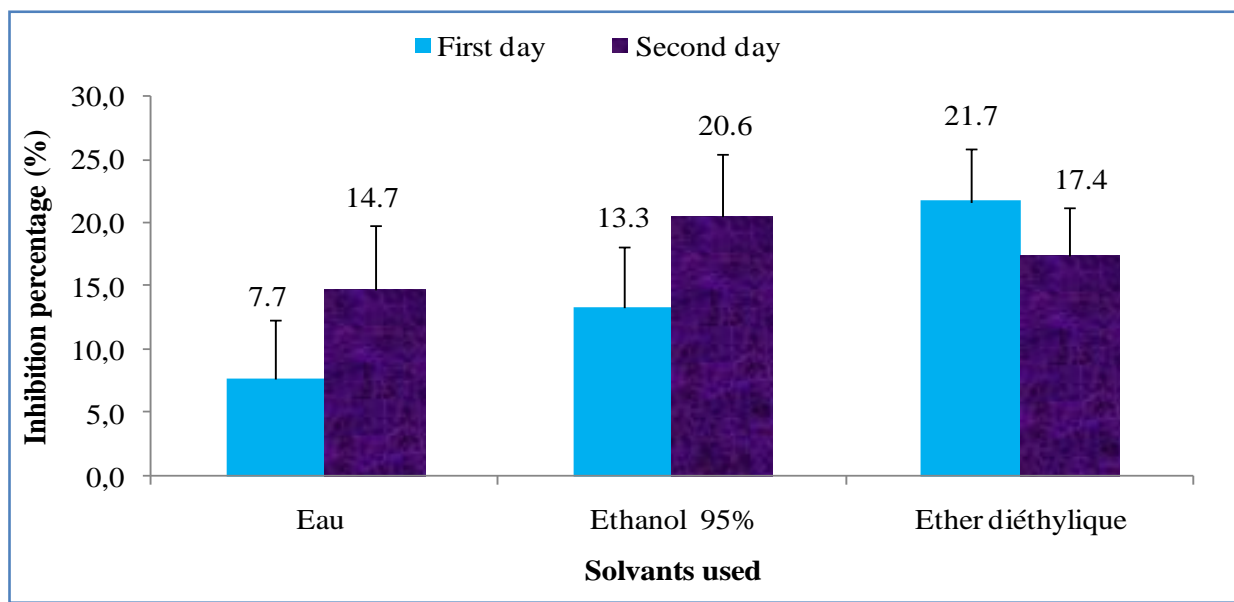

Fig-2: Percentage inhibition of water, $95 \%$ ethanol and diethyl ether on the strain of $L$. theobromae

Diethyl ether exhibited a high inhibition rate just after one day of incubation (21.7\%) while ethanol achieved a rate of $20.6 \%$ after two days of observation. As for water, a low PI of $14.7 \%$ was revealed after two days of incubation.

\section{Extracts of fresh leaves}

Figure 3 below illustrates the antifungal activity of the fresh leaves of the plants used, after two days of incubation.
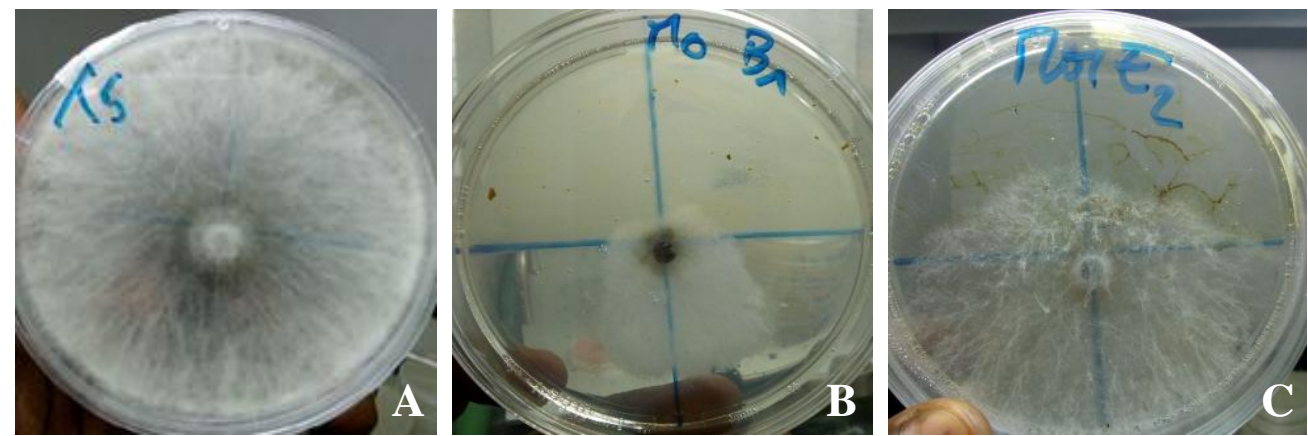

Fig-3: A: Control strain of L. theobromae, B: Raw extract of fresh leaves of M. oleifera and C: Ethereal extract of fresh leaves of M. oleifera against the strain of $L$. theobromae after 2 days of incubation

It should be noted from Fig. 3 that the Petri dishes are only half filled with the strain of $\mathrm{L}$. theobromae unlike that of the control, which is completely filled after two days of incubation.

\section{Raw extracts}

Figure 4 below illustrates the PI of the raw extracts of the fresh leaves studied on the strain of $L$. theobromae. 


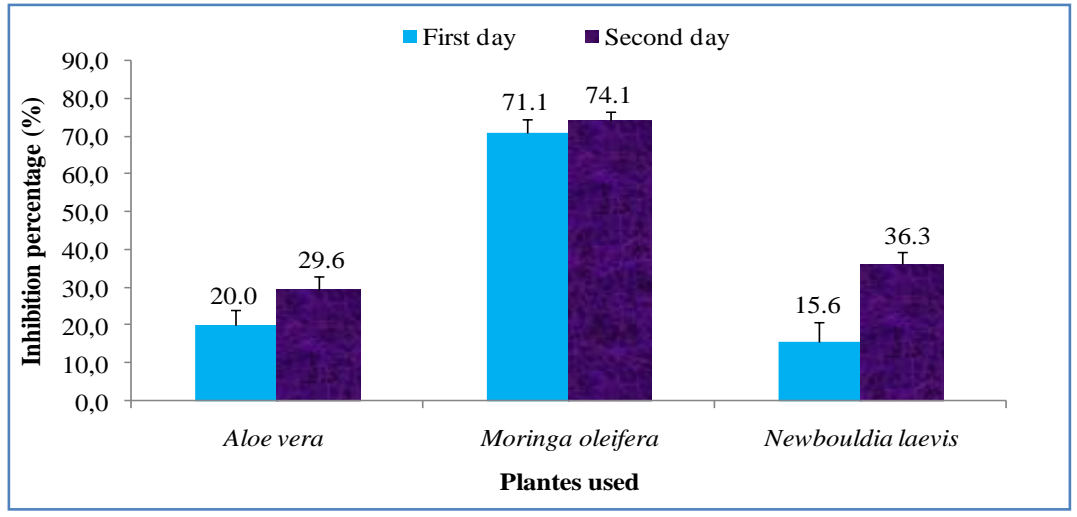

Fig-4: Percentage inhibition of crude extracts from fresh leaves of $A$. vera, M. oleifera and $N$. laevis on the $L$. theobromae strain

It appears from this figure that the raw extract of fresh leaves of $M$. oleifera exhibited a high PI during the two days of incubation, respectively 71.1 and $74.1 \%$ while the raw extract of fresh leaves of $N$. laevis posted a weak PI after one day, which is $15.6 \%$. As for the raw extract of $A$. vera, a weak PI of $29.6 \%$ was released after two days of incubation.

\section{Macerated extracts}

The fresh leaves macerated in aqueous, ethanolic and ethereal extracts revealed the PI (after two days of incubation) on the L. theobromae strain as illustrated in figure 5 below.

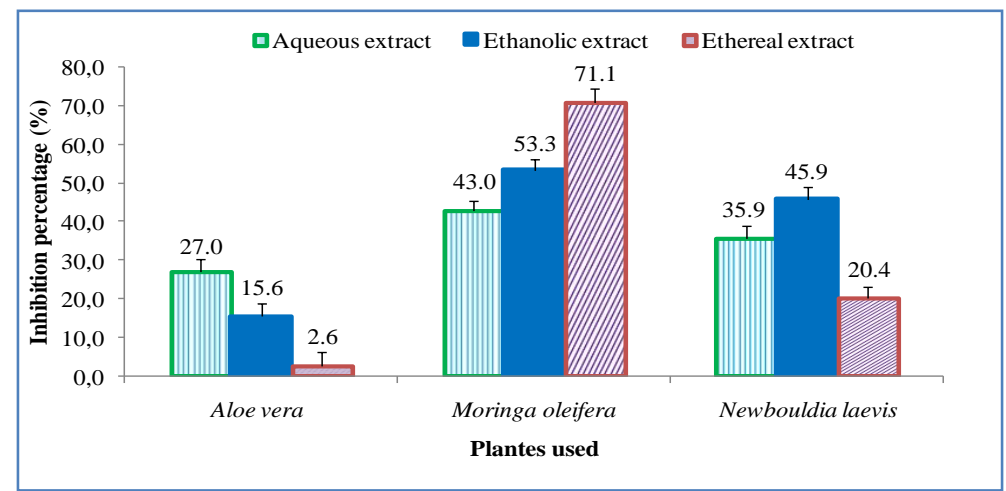

Fig-5: Percentage inhibition of extracts of fresh leaves of $A$. vera, M. oleifera and $N$. laevis on the L. theobromae strain after two days of incubation

The observation in figure 5 above shows that the aqueous, ethanolic and ethereal extracts of $M$. oleifera display higher PI, 43.0; 53.3 and $71.1 \%$ on the L. theobromae strain after two days of evaluation of antifungal activity compared to those of other plants.

\section{Extracts of dry leaves}

The inhibition percentages of aqueous, ethanolic and ethereal extracts of dry leaves of $A$. vera, $M$. oleifera and $N$. laevis on the L. theobromae strain are illustrated in the following figure 6.

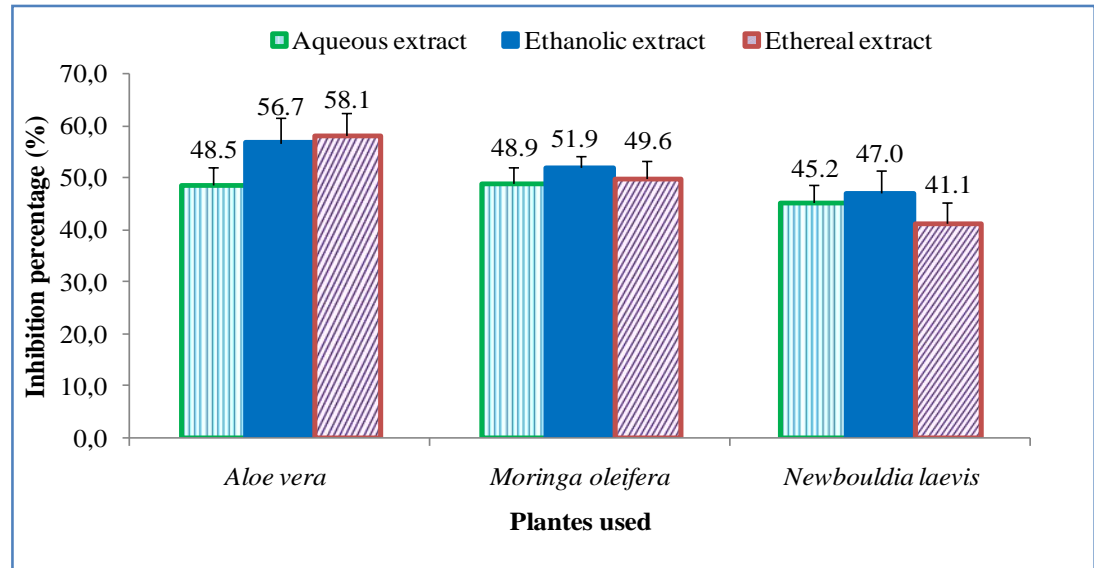

Fig-6: Percentage inhibition of extracts of dry leaves of A. vera, M. oleifera and N. laevis on the L. theobromae strain after two days of incubation 
Kwembe JTK et al., Sch Bull, May, 2020; 6(5): 123-130

In light of figure 6 , it appears that after two days of incubation, the ethereal extract of $A$. vera presented a high PI, $58.1 \%$ followed by the ethanolic extract of the same plant, or $56.7 \%$ on the $L$. theobromae strain. In addition, all the extracts from $N$. laevis did not present significant enough PI.

\section{Maximum growth time}

Tables 1 and 2 show respectively the maximum growth time MGT (in days) of $L$. theobromae against the various extraction solvents and extracts from the plants used.

Table-1: Maximum growth time of the L.theobromae strain against extraction solvents

\begin{tabular}{|l|c|}
\hline Extraction solvent & Mycelial growth time (day) \\
\hline Control & 2 \\
\hline Distilled water & 3 \\
\hline Ethanol 95\% & 3 \\
\hline Diethyl ether & 3 \\
\hline
\end{tabular}

Table-2: Maximum growth time of the L. theobromae strain against the extracts of the plants studied

\begin{tabular}{|l|c|c|c|c|c|c|c|}
\hline \multirow{3}{*}{ Plants used } & \multicolumn{9}{|c|}{ Mycelial growth time (day) } & \multicolumn{2}{c|}{ Ethereal extract } \\
\cline { 2 - 8 } & Raw extract & \multicolumn{2}{|c|}{ Aqueous extract } & Ethanolic extract & \multicolumn{2}{c|}{ Deaves } & Dry leaves \\
\cline { 2 - 8 } & Fresh leaves & Fresh leaves & Dry leaves & Fresh leaves & Dry leaves & Fresh leaves \\
\hline Aloe vera & 3 & 3 & 5 & 3 & 4 & 3 & 4 \\
\hline Moringa oleifera & 6 & 4 & 4 & 5 & 4 & 5 & 4 \\
\hline Newbouldia laevis & 3 & 3 & 5 & 4 & 4 & 3 & 4 \\
\hline
\end{tabular}

It appears from Table 1 that the TCM of $L$. theobromae is only 2 days for the control and 3 days for the solvents, moreover, for the extracts of the plants, the growth time varied from 3 to 6 days

\section{Water content}

The fresh leaves of the plants studied were subjected to the drying test and revealed the water contents illustrated in figure 7 below.

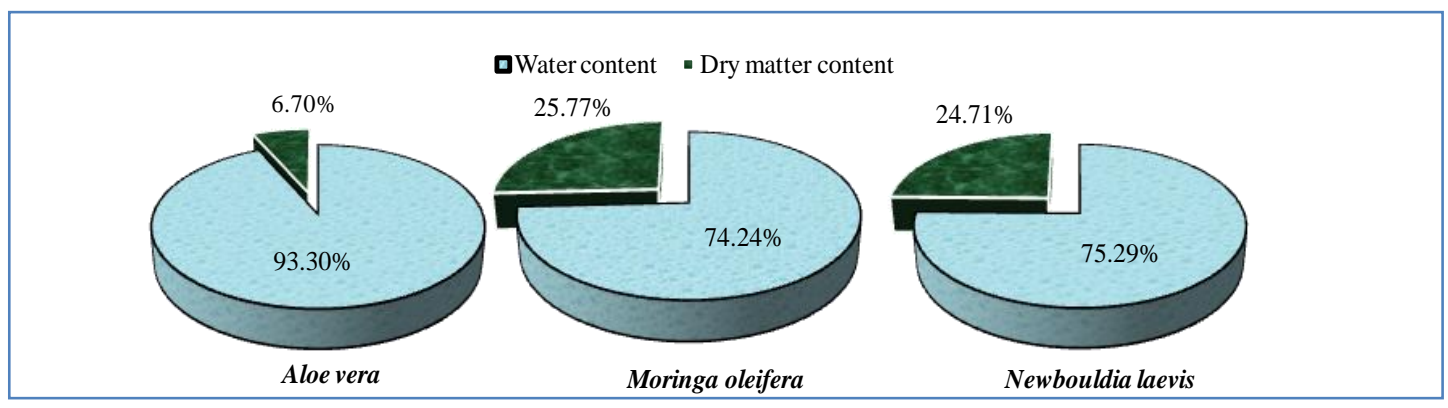

Fig-7: Water content of fresh leaves of $A$. vera, M. oleifera and $N$. laevis

It is evident that the fresh leaves of $A$. vera have a high water content of $93.3 \%$ however those of M. oleifera and $N$. laevis have relatively low and similar contents, respectively 74.2 and $75.3 \%$.

\section{Total extract content}

The extraction yields after complete evaporation of the solvents from the maceration of the dry leaves are illustrated in the following figure 8 .

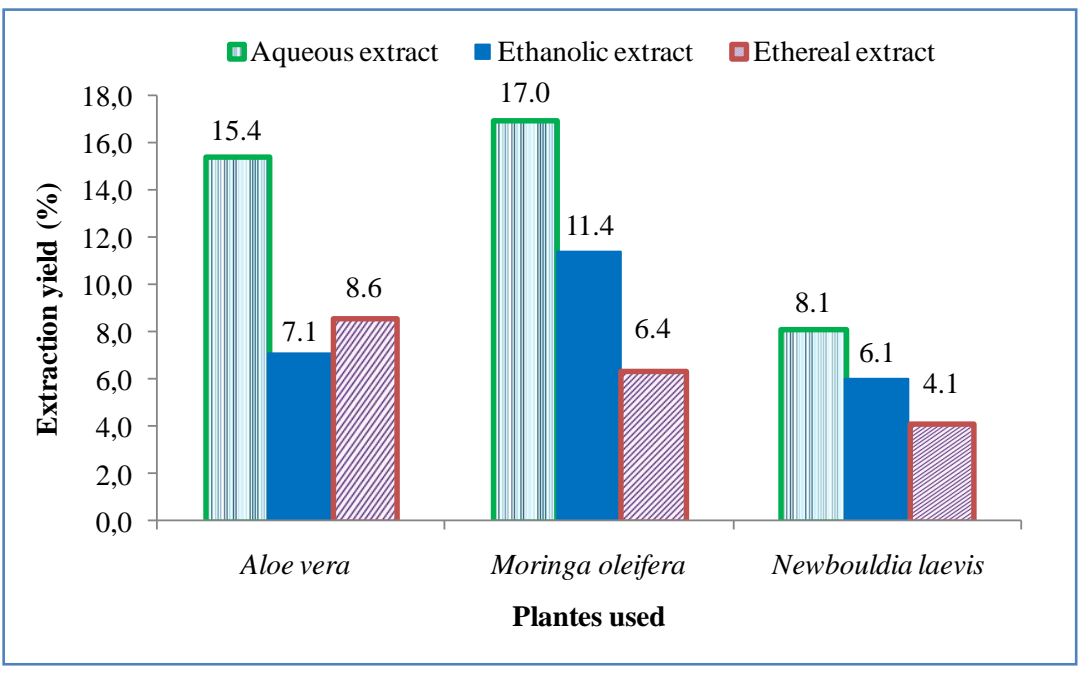

Fig-8: Yield of total extracts of $A$. vera, M. oleifera and $N$. laevis 
With regard to this figure, it follows that the extraction yield of $\mathrm{M}$. oleifera by water is higher at $17.0 \%$ followed by that of $\mathrm{A}$. vera is $15.4 \%$ while that of extraction of $N$. laevis by ether is the lowest at $4.1 \%$.

\section{DISCUSSION}

The L. theobromae strain is expected to achieve maximum growth in vitro by completely occupying the surface of the culture medium (Fig. 2). The growth rate of the control increases more quickly by occupying 33.33 and $100 \%$ of the surface respectively after one and two days of incubation.

Faced with extraction solvents, the strain is not inhibited (Fig. 2), hence the maximum growth time is only one day longer than that of the control (Tab.1). It should be stated that water, ethanol $95 \%$ and diethyl ether have no (considerable) antifungal activity on $L$. theobromae since they all have PI values below $25 \%$ [20].

Although the L. theobromae strain exhibited low sensitivity on water, ethanol $95 \%$ and diethyl ether, their PI are significantly different $(\mathrm{p}$ value $=0.00335)$. Thus, it should be noted that diethyl ether has a high PI (21.7\%) after one day of incubation, but this value decreases significantly on the second day (17.4\%). However, ethanol displays growing PI, going from $13.3 \%$ after one day to $21.1 \%$ after two days of incubation. These two readings (which oppose each other) made on diethyl ether and $95 \%$ ethanol would be justified by the fast or slow volatility of each solvent over time.

In figure 2, the PI of water and ethanol have an ascending pace from the first to the second day, which defines the second day as the right time to compare the PI of the different extracts with each other.

Furthermore, in the presence of plant extracts, the L. theobromae strain is considerably slowed down (Fig. 3) and this prolongs the MGT which goes from 2 days for the control to 3 or 6 days (Tab. 3) depending on the type of extract and nature of plant tested.

The PI of crude extracts are generally high compared to that of the control and are significantly very different from each other $\left(p\right.$ value $\left.=2 \cdot e^{-16}\right)$.

Extracts from fresh leaves of $M$. oleifera have significant antifungal activities against the strain of $L$. theobromae (Fig. 5) compared to extracts from fresh leaves of $A$. vera and $N$. laevis. M. oleifera ethereal extract has the highest PI at $71.1 \%$. The antifungal molecules contained in this extract could be the basis of this more pronounced activity.

Even though all the extracts from the dry leaves are all antifungal (Fig. 6), the strain of $L$. theobromae is more sensitive first to ethereal $(58.1 \%)$ and ethanolic (56.7\%) extracts of $A$. vera followed by ethanolic $(51.9 \%)$ and ethereal $(49.6 \%)$ extract from $M$. oleifera. This observation could be explained by two facts:

The high water content of A. vera $93.3 \%$ (Fig. 7) would justify the low inhibition rate of its crude extract, however that of $M$. oleifera $(74.2 \%)$, did not significantly influence the inhibition rate of the extract ethanolic because the PI of the ethanolic extract of the fresh leaves is $53.3 \%$ while that of the dry leaves is $51.9 \%$ ( $\mathrm{p}$ value $=0.9221)$ but has led to a significant drop in PI of the ethereal extract of fresh leaves: 71.1 to $49.6 \%$ for the same extract but dry leaves (Fig 5 and 6) of M. oleifera.

The high yields of total extracts (Fig 8) from $A$. vera and $M$. oleifera, thus increased the concentration of vegetative matter in the extracts tested.

Furthermore, the water content of $M$. oleifera $(74.2 \%)$ is not too different from that found by Broin, ie $75 \%$ [21]. The extraction yield depends on the nature of the plant and the solvent used. The yields of aqueous extract of all the plants studied are high compared to those of ethanolic and ethereal extracts but are all low to that of aqueous extract of the leaves of Cupressus lusitanica $(21.20 \%)$ found by Tsopmbeng in Cameroon [22]. As for $N$. laevis, the yield of methanolic extract obtained by Minaflinou in Benin is 14\% [23] and that of ethanolic extract by Hounzanbge, $12.8 \%$ [24], are all very high compared to the yield of the ethanolic extract in our study, ie $6.1 \%$. These differences would be justified by the habitat and the geographic study area.

The PI of the raw extract of $M$. oleifera (74.1\%) remains the highest with a MGT of 6 days compared to the PI of the extracts of the same plant macerated in various solvents (in fresh or dry state). This more pronounced activity would find its justification in the natural composition of the plant, which once macerated; $M$. oleifera partially loses its antifungal compounds such as essential oils. This plant would have molecules acting in symbiosis against this fungus $L$. theobromae.

In addition to the classification of degree (PI) of antifungal activity of plants [20]: very active plant with the PI between 75 and 100\%; active plant whose PI vacillates between 50 and $75 \%$, moderately active plant with the PI between 25 and $50 \%$ and finally little or non-active plant whose PI is less than $25 \%$; in our study, the ethanolic extract of $A$. vera $(56.7 \%)$, the ethereal extract from the same plant $(58.1 \%)$ and the ethanolic extract from the dry leaves of $M$. oleifera $(51.9 \%)$ and fresh leaves from the same plant ( $53.3 \%)$ classify $A$. vera and $M$. oleifera among the "active plants". 
Furthermore, according to the classification criteria established by Abdellatif [25] as taken up by Hajji [26], M. oleifera in the present study could be classified among the plants with "excellent activity" taking into account PI of its crude extracts and ethereal fresh leaves of 74.1 and $71.1 \%$ respectively.

There were very significant differences between the PI of ethereal extracts of dried leaves ( $p$ value $=0.0001)$, but significant for those of ethanolic extracts ( $\mathrm{p}$ value $=0.0129$ to $95 \%$ ), however, there is no significant difference between the PI of the aqueous extracts ( $p$ value $=0.2400)$. On the basis of these observations, it should be stated that the extraction solvent plays a very preponderant role in the selective extraction of the antifungal compounds from plants. The latter each have specific properties, since they are not of the same kind and above all their profiles as secondary metabolites would also be very different. Thus the antifungal activity on the strain of $L$. theobromae is due to the less polar molecules for the leaves of $A$. vera and $M$. oleifera.

Thus taking into account the diversity of chemical molecules that these plants can contain and their antifungal properties, a more in-depth study is to be considered in our next investigations in order to define the qualitative and quantitative compositions of these medicinal plants.

\section{CONCLUSION}

This study was focused on the in vitro evaluation of the antifungal activity of extracts of Aloe vera, Moringa oleifera and Newbouldia laevis on the Lasiodiplodia theobromae strain. It was found that all the dry leaves of the plants studied showed interesting PI, firstly $M$. oleifera with a higher inhibition power (74.1\% for the raw extract of dry leaves) followed by $A$. vera (58.1\% for the ethereal extract of dry leaves). But the leaves of $N$. laevis are less antifungal. The solvents used for extraction, although they do not have an antifungal supply, but play a key role in the extraction of plant-specific secondary metabolites depending on whether they are polar or non-polar. These plants being naturally different could also have different compositions in terms of active principles which they contain.

In view of the results obtained, determining the composition of phytochemical groups and identifying the active principle responsible for this antifungal activity will be the subject of our future investigations.

\section{ACKNOWLEDGEMENT}

- VLAAMSE INTERUNIVERSITAIRE RAAD (VLIR-UOS): For the financial means without which the realization of this work would not be easy.
- Professor Geert Baert of the University of Ghent / Belgium: for his coordination and assistance in the acquisition of some laboratory equipment and especially during an internship at the University of Ghent.

\section{REFERENCES}

1. Soro, D., Koné, M. W., Kone, D., \& Kamanzi, K. (2012). Evaluation de l'activite antifongique par bioautographie de quelques plantes medicinales de côte d'ivoire contre deux formes speciales de Fusarium oxysporum. Agronomie Africaine, 24(1), 19-28.

2. Coraf. (2010). Des extraits végétaux à la place des produits de synthèse, $\mathrm{N}^{\circ} 56$ juillet à septembre, $16 \mathrm{p}$.

3. Icco (International Cocoa Organisation). (2000). Bilan de la conjoncture Cacaoyère. 106e Réunion, Londres. 9 pp.

4. Mbenoun, M., Momo Zeutsa, E. H., Samuels, G., Nsouga Amougou, F., \& Nyasse, S. (2008). Dieback due to Lasiodiplodia theobromae, a new constraint to cocoa production in Cameroon. Plant Pathology, 57(2), 381-381.

5. Punithalingam, E. (1976). Botryodiplodia theobromae, CMI descriptions of pathogenic fungi and bacteria. No. 519. Commonwealth Mycological Institute, Kew, Surrey, England.

6. Khanzada, M.A., Lodhi, A.M., Shahzad, S., (2004). Mango dieback and gummosis in Sindh Pakistan caused by Lasiodiplodia theobromae. Plant Health Progress On-line http://www.plantmanagementnetwork.org.

7. Ko, W. H., Wang, I. T., \& Ann, P. J. (2004). Lasiodiplodia theobromae as a causal agent of kumquat dieback in Taiwan. Plant disease, 88(12), 1383-1383.

8. Kannan, C., Karthik, M., \& Priya, K. (2010). Lasiodiplodia theobromae causes a damaging dieback of cocoa in India. Plant Pathology, 59(2).

9. Alvindia, D. G., \& Gallema, F. L. M. (2017). Lasiodiplodia theobromae causes vascular streak dieback (VSD)-like symptoms of cacao in Davao Region, Philippines. Australasian plant disease notes, 12(1), 54.

10. De Jaeger, C., Voronska, E., Fraoucene, N., \& Cherin, P. (2012). Exposition chronique aux pesticides, Rôle de notre alimentation. Revue" Médecine et Longévité". Institut de médecine et physiologie de la longévité-IDJ-PARIS, Version du 22 Janvier 2018.

11. Spotts, R. A., \& Cervantes, L. A. (1986). Populations, pathogenicity, and benomyl resistance of Botrytis spp., Penicillium spp., and Mucor piriformis in packinghouses. Plant Disease, 70(2), 106-108.

12. Avenot, H., Morgan, D.P., \& Michailides, T.J. (2008). Resistance to pyraclostrobin, boscalid and multiple resistances to pristine (pyraclostrobin + 
boscalid) fungicide in Alternaria alternata causing Alternaria late blight of pistachios in California. Plant Pathology, 57(1), 135-140.

13. Krieger, R.I. (2001). Handbook of pesticide toxicology, 1 - Principles, 2nd ed. San Diego, CA, Academic Press, 1908.

14. Unnikrishnan, V., \& Nath, B.S., (2002). Hazardous chemicals in foods. Indian J. Dairy Biosci, 11, 155-158.

15. Ventura, J., Fernandes, P., Meira, D., Sales, M., \& Costa, H. (2015). Antifungal activity of plant extracts with potential to control plant pathogens in pineapple.

16. Sidi, I. Y. M. S., Olounlade, P. A., Yaoitcha, A., Dedehou, V. F. G. N., AloXwanou, G. G., Azando, E. V. B., \& Hounzangbe-Adote, M. S. (2017). Principales espèces médicinales utilisées en médecine vétérinaire au Bénin: disponibilité et caractéristiques dendrométriques. Bull. Anim. Hlth. Prod. Afr, 65, 209-220.

17. Azando, E. V. B., Olounladé, A. P., HounzangbeAdote, M. S., \& Hoste, H. (2011). Effets anthelminthiques in vivo de la poudre de feuilles de Zanthoxylum zanthoxyloüdes et de Newbouldia laevis sur les nématodes parasites gastrointestinaux des chevreaux Djallonké. International Journal of Biological and Chemical Sciences, 5(3).

18. Lomba, L., \& Ndjele, B.M.L. (1998). Contribution à l'étude de la phytodiversité de la Réserve Forestière de la Yoko. Annales Fac des Sciences 25.

19. Nshimba, S. (2008). Etude floristique, écologique et phytosociologique des foréts de l'ile Mbiye à Kisangani, R.D. Congo. Thèse de doctorat inedite, ULB, 255.

20. Bouazza, F., et Hassikou, R. (2011). Activité antifongique in vitro de la pulpe foliaire d'Aloe vera. Bull. Soc. Pharm. Bordeaux, 150(1-4), 95106

21. Broin, M.P. (2005). Composition nutritionnelle des feuilles de Moringa oleifera. In Moringanews, available on http://www.moringanews.org/documents/Compofe uilles.pdf

22. Tsopmbeng, N. G., Megatche, C. J. P., Lienou, J. A., Yaouba, A., Djeugap, F. J., \& Fontem, D. A. (2014). Évaluation des activités antifongiques des extraits de plantes contre Phytophthora colocasiae, agent causal du mildiou du taro (Colocasia esculenta (L.) Schott). Journal of Applied Biosciences, 81, 7221-7232.

23. Sidi, I. Y. M. S., Azando, E. V. B., Olounlade, P. A., \& Hounzangbe-Adote, M. S. (2015). Effets combinés des feuilles de Newbouldia laevis et de Zanthoxylum zanthoxyloïdes sur les nématodes parasites gastro-intestinaux des ovins Djallonké. International Journal of Biological and Chemical Sciences, 9(4), 2078-2090.

24. Hounzangbé, A.M.S. (2004). Propriétés anthelminthiques de 4 plantes tropicales testées in vitro et in vivo sur les nématodes gastrointestinaux chez les petits ruminants Djallonké. (Thèse de doctorat en sciences). FAST- Université d'Abomey-Calavi, 205.

25. Abd-Ellatif, S., Abdel Rahman, S. M., \& Deraz, S. F. (2011). Promising antifungal effect of some folkloric medicinal plants collected from ElHammam habitat, Egypt against dangerous pathogenic and toxinogenic fungi. ARPN J. Agric. Biol. Sci, 6(9), 25-32.

26. HAJJI, H. Evaluation in vitro de l'activité antifongique de quatre plantes médicinales marocaines sur cinq champignons phytopathogènes. Revue Marocaine de Protection des Plantes, (10). 